\section{The decline of Rome to a fast-food empire}

\section{from Richard Hodges}

A NUMBER of recent archaeological publications provide evidence of a socioeconomic transition that occurred in the Roman Empire as it declined and fell 'the greatest, perhaps the most awful scene in the history of mankind', according to Edward Gibbon ${ }^{1}$.

Whereas Gibbon's analysis of the faltering empire did not include such a transition, it had been anticipated by Henri Pirenne in his famous book Mohammed and Charlemagne, published half a century ago, the theme of which was returned to last year by $\mathrm{C}$. $R$. Whittaker ${ }^{2}$ who argued the revolutionary hypothesis that increased state exactions in kind in the later empire, and the effective decommercialization of the economy, reflected a reorganization of the means of exchange rather than economic decline. There was no fall, he contends, in production or exchange, only a decline in the entrepreneurial commodity market ${ }^{3}$. This reorganization, he argues, forms the foundation on which the medieval economy was constructed. But with such patchy documentation to support his argument, Whittaker, like Pirenne before him, is unable to measure change in production or distribution with any precision.

Archaeological evidence alone will adjudicate on this issue 4 , and a recent volume of archaeological surveys in the Mediterranean area ${ }^{5}$ pointedly illustrates one aspect of Whittaker's thesis. There was undeniably a change in the organization of production in the countryside towards the end of the fourth century AD; far fewer sites are characterized by the highly distinctive African Red Slip wares of the fifth and sixth centuries in all parts of the Mediterranean basin. Sadly, though, little attention is drawn to this fact - an occasion where archaeological statistics appear to be meaningful ${ }^{6}$. But what exactly does this reorganized rural pattern mean?

Alistair Small has excavated a Roman villa at San Giovanni di Ruoti in Basilicata that appears to be typical of the later Roman settlement system in Italy ${ }^{7}$. By early Roman standards it is a modest affair, but Small contends it is a normal residence of a dominus, a landlord in the fifth to sixth century. Of particular interest are the faunal and ceramic assemblages from the middens around the villa. As many as 40 per cent of the bones in the early fifthcentury midden and 65 per cent in the later fifth-century midden are from pigs. The traditional balanced blend of meat consumption and stock-rearing on rural estates seems to have been abandoned in favour of the short-term fast production of pork. A passion for chops became the fashion of the time. However, while the animal bones reveal a trend towards fastfood processing, the pottery assemblage confirms the persistence, albeit in a reorganized form, of regional productiondistribution services for ceramics. Several of the contributors to the volume in which Small's essay appears note the distinctive character of the later Roman economy as the state's role begins to diminish at a regional level.

Related information comes from the first part of David Whitehouse's important excavations at the foot of the Palatine ${ }^{8}$. From a study of the animal bones found there, Graeme Barker concludes that about 40 per cent of the meat eaten at this site was pork - a finding which he argues may be illuminated by the Theodosian code (AD 438) which describes guilds of pork suppliers who brought pigs from all parts of Italy for consumption by the poor of Rome. Pork, it seems, was the dole money of the Imperial City. Yet, as at S. Giovanni, the pottery assemblage at the Schola Praeconum indicates the existence of a vibrant market system. Large numbers of east Mediterranean amphorae and North African tablewares from the middens demonstrate far-flung mercantile connections of growing importance. So how does this evidence square up with Whittaker's thesis?

Two points emerge from the recent archaeological reports. First, short-term fast-food production and a trend towards more regionally devolved ceramic industries seem to have accompanied the drop in density of rural sites. Second, there were changes in distribution. Tax in kind, to judge from the pattern of pork consumption, was as significant as Whittaker anticipated. However, in contrast to the regionally discrete patterns of ceramic distribution evident in southern Italy, a marked increase in the volume of imported pots is evident in cities such as Rome ${ }^{9}$. The major cities, in other words, were booming and attracting the rural poor, the recipients provinces, as Whittaker notes. Rome's Indian Summer, like that of the wealthier villas such as S. Giovanni, was notable for its emphasis on short-term consumption.

Whether the volume of production in this reorganized community remained static, as Whittaker contends, or declined, as seems more probable, will only be clear when the many regional archaeological surveys of the moment in Italy are completed. But all the current work demonstrates that these fifth-century developments reflect that time was running out for the Roman Empire. The state system began to gasp and collapse in the early sixth century before the Byzantine and then the Lombard invasions of the peninsula. The system of ports and villas fell apart soon after AD 500, leaving ruins which fascinated the early medieval elite as they do tourists today. Whittaker's thesis and his fascinating reworking of Gibbon's drama is to some extent confirmed by the archaeology of the period. The scale of change and the eventual collapse must have seemed every bit as awful to those who experienced it as Gibbon's gothic description contends.

1. Gibbon, E. The Decline and Fall of the Roman Empire Harmondsworth, 1983).

2. Whittaker, C. R. in Trade in the Ancient Economy (eds Garnsey, P.. Hopkins, K. \& Whittaker, C. R.) 178 (1.ondon, 1983)

3. Hopkins, $\mathrm{K}$. in Trade in the Ancient Economy (eds Garnsey, P. Hopkins, K. \& Whittaker C. R.) 178 (1.ondon, 1983).

4. Hodges, R. \& Whitehouse, D. Mohammed, Charlemagne and the Origins of Europe (I.ondon, 1983).

5. Keller, D. R. \& Rupp. D. W. (eds) Archaeological Survey in the Mediterranean Area (BAR int. ser. 155, (ixford, 1983).

6. Hodges, R. \& Whichouse, D. in Mohammed, Chartemasne and the Orisins of Europe, 33 (London, 1983).

Lo Scavo di S. Giovanni di Ruotied il Periodo Tardoantico in Basilicata (Adriatica, Bari, 1983).

8. W'hitehouse, D. et al. The Schola Praeconum I, Papers of the British School at Rome, 50 (1982); 53 (1983).

9. Fulford, M. G. Reading Medieval Stud. 6, 68 (1980).

Richard Hodges is in the Department of Prehistory and Archaeology, University of Sheffield, Sheffield S10 2TN. of the pork dole, leaving agri deserti in the (abridges by l.ow, D. M.) 902 (Penguin.

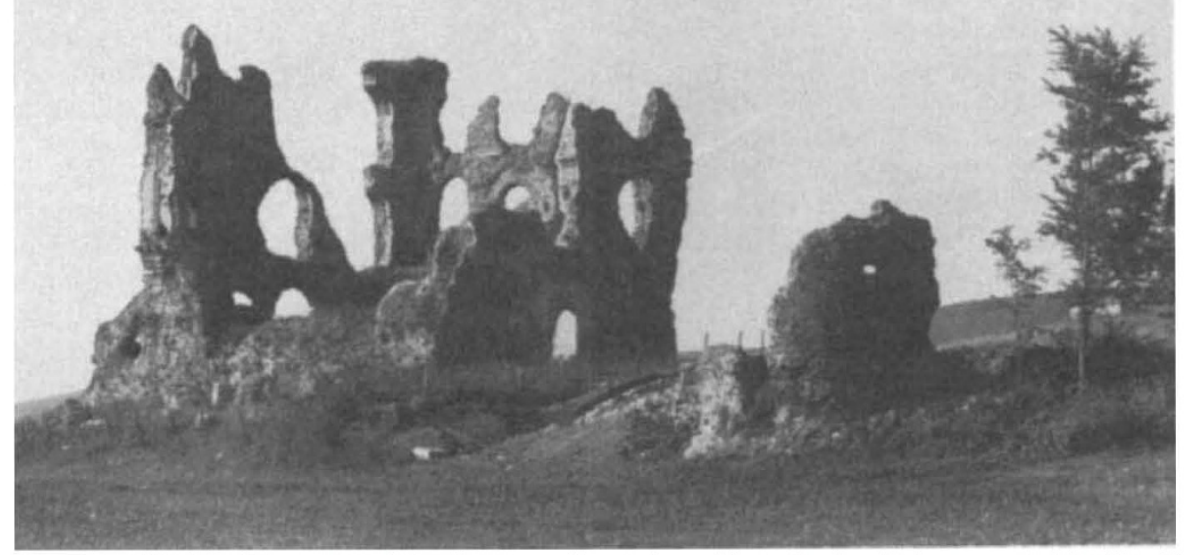

Remains of a 5th-7th century later Roman villa at Anguillara, Lazio, Italy excavated by David Whitehouse for the British School at Rome. Photograph by courtesy of David Whitehouse. 